\title{
Characteristics of anti-Vibrio harveyi compounds produced by Bacillus spp. isolated from shrimp ponds
}

\author{
IMAN RUSMANA ${ }^{1, \boldsymbol{v}}$, ISRAMILDA ${ }^{\mathbf{1}}$, ALINA AKHDIYA ${ }^{2}$ \\ ${ }^{1}$ Department of Biology, Faculty of Mathematics and Natural Sciences, Institut Pertanian Bogor. Jl. Agatis, Campus IPB Dramaga, Bogor 16680, West \\ Java, Indonesia. Tel./fax.: +62-251-8622833, `email: irusmana@apps.ipb.ac.id \\ ${ }^{2}$ Indonesian Research Center for Agriculture Biotechnology and Genetic Resources. Jl. Tentara Pelajar No. 3A, Cimanggu, Bogor 16111, West Java, \\ Indonesia
}

Manuscript received: 23 September 2021. Revision accepted: 18 October 2021.

\begin{abstract}
Rusmana I, Isramilda, Akhdiya A. 2021. Characteristics of anti-Vibrio harveyi compounds produced by Bacillus spp. isolated from shrimp ponds. Biodiversitas 22: 4872-4879. Pathogenic Vibrio spp. such as Vibrio vulnificus, V. alginolyticus, V. fluvialis, V. anguillarum, and $V$. harveyi caused shrimp diseases. The application of bacterial probiotics can control the growth of pathogenic Vibrio in shrimp. Bacillus spp. can produce antimicrobial compounds that inhibit the growth of pathogenic Vibrio spp. Isolation of Bacillus from several pond water samples, pond sediment, and shrimp intestines was successfully collected 175 isolates of Bacillus spp. Three isolates, i.e., Ltw54, Lts36, dan Lts40 had a high inhibitory index and stability in inhibiting the growth of Vibrio harveyi. Verification assay showed that Bacillus sp. Lts40 had the highest antimicrobial activity. The competition assay showed that Bacillus sp Lts40 isolates inhibited the growth of $V$. harveyi up to $81,8 \%$. The antimicrobial compound produced by Bacillus sp. Lts 40 was stable at the pH range of 3-11 and remained stable after heating at $100^{\circ} \mathrm{C}$ for 20 minutes. The purification results using the chromatographic filtration technique showed that the protein fraction with a molecular weight of $47,38 \mathrm{kDa}$ effectively inhibited $V$. harveyi growth. Bacillus sp. Lts40 isolate has potential application as a probiotic agent in shrimp ponds to control the growth of $V$. harveyi that causes luminous vibriosis diseases and the antimicrobial substance is potentially to be developed and produced as an anti- $V$. harveyi product that can be applied in a shrimp hatchery.
\end{abstract}

Keywords: Antimicrobial substances, Bacillus, shrimp pathogen, Vibrio harveyi

\section{INTRODUCTION}

Some pathogenic Vibrio spp. are leading to various 'vibriosis' diseases. These diseases have a significant negative impact on shrimp production (de Souza Valente C and Wa 2021). In shrimp larval rearing, one of the primary disease problems is the zoea syndrome. This disease could result in larval mortality of up to $90 \%$. Pathogenic Vibrio spp. such as Vibrio vulnificus, V. alginolyticus, V. fluvialis, $V$. anguillarum dan $V$. harveyi are the main factors causing the diseases. The most important pathogenic Vibrio in shrimp cultures is $V$. harveyi. This bacterium is the main cause of bacterial infection in shrimp that can occur starting from the larval level. Bacterial attack at the larval stage can cause mass mortality (Roza 1993). Vibrio harveyi (Johnson \& Shunk 1936) Baumann et al. (1981) is the dominant group of vibrios from the shrimp pond sediment $(40 \%)$ and shrimp gut (40\%). Pathological symptoms of the diseases were indicated by loss of digestive capacity and nutrient absorption which result in delayed shrimp molting and subsequently causing the death of the larvae with cumulative mortality up to $100 \%$ at stage two of zoea (Kumar et al. 2017).

The use of probiotic bacteria is an alternative way to control diseases caused by pathogenic bacteria in shrimp ponds (de Souza Valente and Wa 2021). Probiotics are live microbes that exert beneficial effects on the host by altering the microbial community, improving nutritional value, enhancing the host defense mechanism to disease, and improving environmental quality (Verschuere et al. 2000). Some probiotic bacteria could produce bactericidal or bacteriostatic compounds that inhibit the growth of pathogenic bacteria. Shrimp probiotics commonly used are Bacillus that can produce antimicrobial compounds. Bacillus can produce antimicrobial polypeptides such as bacteriocins that can inhibit the growth of other bacteria (Irina et al. 2001). Bacillus is present in the sediments and digestive tract of shrimp (Verschuere et al. 2000). Application of Bacillus sp. as a probiotic in shrimp culture improved resistance performance of Pacific white shrimp (Litopenaeus vannamei) against $V$. harveyi. Probiotic applications significantly improved shrimp growth parameters such as weight gain, average daily growth, feed conversion ratio, and survival rate than those of the control against $V$. harveyi (Harpeni et al. 2018). However, information on the characteristic of the antimicrobial compounds produced by the indigenous Bacillus spp. isolated from Indonesian shrimp ponds are still limited. Therefore, this paper describes the characteristics of antimicrobial activity against $V$. harveyi and molecular weight of the compounds produced by the indigenous Bacillus spp. isolated from several areas of Indonesian shrimp ponds and their activity stability to $\mathrm{pH}$ and temperature treatments. 


\section{MATERIALS AND METHODS}

\section{Screening of bacterial isolates producing antimicrobial compounds}

Three isolates of Bacillus spp. (Lts36, Lts40, and Ltw54 isolates) and $V$. harveyi from the collection of Microbiology Laboratory, Department of Biology, IPB University) were re-cultured in a seawater complete (SWC) agar medium. One liter SWC medium consists of $5 \mathrm{~g}$ yeast extract, $5 \mathrm{~g}$ peptone, $3 \mathrm{~g}$ beef extract, $600 \mathrm{~mL}$ seawater, and $400 \mathrm{~mL}$ distilled water. Inoculated SWC were incubated at room temperature $\left( \pm 26^{\circ} \mathrm{C}\right)$ for two days. The antimicrobial activity of Bacillus spp. was assayed against $V$. harveyi using a double layer method. A total of $50 \mu \mathrm{L}$ of the $V$. harveyi culture with the cell's density of $10^{8} \mathrm{CFU} / \mathrm{mL}$ was suspended in $50 \mathrm{~mL}$ of a melted semi-solid SWC medium. As much as $10 \mathrm{~mL}$ of the culture was poured on a solid surface SWC medium plate.

Furthermore, the bacterial isolates of Bacillus spp. were inoculated triplicates onto the plates and then incubated for 24 hours at room temperature $\left( \pm 26^{\circ} \mathrm{C}\right)$. The bacterial isolates that produce antimicrobial compounds form the inhibition zone around the bacterial colony. Calculation of inhibition index using the formula as follows:

Inhibition index $=($ diameter of inhibition zone - diameter of bacterial colony $)$ Diameter of bacterial colony

\section{Growth inhibition assay in mixed cultures of Bacillus spp. isolates against Vibrio harveyi}

Growth inhibition assay was carried out using mixed cultures in a flask on the SWC liquid medium. The coculture used different ratios of the selected Bacillus sp. and $V$. harveyi inoculum. The inoculum ratios of the $V$. harveyi and the selected Bacillus sp were 1:1, 1:2, 1:4, and 1:10, respectively. Five flasks containing $50 \mathrm{~mL}$ of the SWC liquid medium were inoculated with $100 \mu \mathrm{L}$ of the $V$. harveyi culture with a cell density of $10^{8} \mathrm{CFU} / \mathrm{mL}$. Then, Bacillus spp. were inoculated at the ratio of 1:1, 1:2, 1:4, and $1: 10$, respectively. Growth control of $V$. harveyi used the same medium without the addition of selected Bacillus sp. inoculum. Incubation was conducted on a shaker incubator for 24 hours at room temperature $\left( \pm 26^{\circ} \mathrm{C}\right)$. The number of cell density were calculated triplicates using a plate count method on SWC agar. The percentage of growth inhibition of $V$. harveyi was calculated using a formula as follows:

Percentage og growth inhibition $=$ $\frac{\text { (control cell density }- \text { treatment cell density) }}{\text { control cell density }} 100 \%$

\section{Determination of optimum production of antimicrobial compounds during bacterial growth}

Bacillus sp isolates that had the highest inhibition activity against $V$. harveyi the A total of $2 \mathrm{~mL}$ of the selected Bacillus sp. culture with the cell density of $10^{8}$ $\mathrm{CFU} / \mathrm{mL}$ was inoculated into $200 \mathrm{~mL}$ of SWC liquid medium and incubated on a shaker for 120 hours at room temperature $\left( \pm 26^{\circ} \mathrm{C}\right)$. Five $\mathrm{mL}$ of cultures were taken every six hours for the inhibitory activity assay. The culture of
Bacillus sp. was centrifuged at the speed of $4500 \mathrm{G}$ for 15 minutes. Assays of antimicrobial activity against $V$. harveyi were conducted using a cell-free supernatant by the disk diffusion method (Lisboa et al. 2006).

\section{Precipitation of antimicrobial compounds using ammonium sulfate}

The selected Bacillus isolate was cultured in the SWC liquid medium and incubated for the optimum time. The cultures were then centrifuged at $4500 \mathrm{~g}$ for 15 minutes at $4^{\circ} \mathrm{C}$. The obtained supernatant was precipitated by salting out method using different concentrations of ammonium sulfate. A total of $500 \mathrm{~mL}$ was precipitated by adding ammonium sulfate gradually ranging from $00-10 \%$ of initial concentration until the final concentration of $70-80 \%$ at $4^{\circ} \mathrm{C}$ using a magnetic stirrer at slow speed. The precipitated proteins were separated from the liquid by centrifugation at $4500 \mathrm{~g}$ for 15 minutes at $4^{\circ} \mathrm{C}$. The precipitate was dissolved using $0.1 \mathrm{M}$ phosphate buffer $\mathrm{pH}$ 7. Suspensions were assayed for their inhibitory activity against $V$. harveyi. The optimum ammonium sulfate for precipitation is the concentration that has the highest inhibitory activity. The inhibitory activity was determined using the disk diffusion method (Lisboa et al. 2006). Protein concentrations were measured using the Bradford method (Bradford 1976). The protein standard for protein measurement was Bovine Serum Albumin (A3294, SigmaAldrich).

\section{Dialysis}

The dialysis process was carried out to wash out ammonium sulfate salt from the precipitated protein. The dialysis membrane preparation was performed by boiling method for 10 minutes in a solution of $2 \%$ sodium carbonate and $0005 \%$ EDTA. Then, the carbonate solution was washed by boiling distilled water for 10 minutes. The dialysis membrane was stored in a buffer solution at $4^{\circ} \mathrm{C}$. One end of the membrane was tied, and the precipitated protein was inserted. The salting-out processes were conducted using $0,01 \mathrm{M}$ phosphate buffer $\mathrm{pH} 7$ with 100 times the total volume of the sample in the membrane. The phosphate buffer was replaced every two hours and incubated at $4^{\circ} \mathrm{C}$ overnight. The dialysis results were assayed for their inhibitory activity against $V$. harveyi using the disk diffusion method (Lisboa et al. 2006), and the protein content was measured using the Bradford method (Bradford 1976).

\section{Purification using a gel filtration column of chromatography}

The protein purification was performed using a Hi Prep 16/60 Sephacryl S-200 high-resolution column chromatography connected to a Sweden AKTA purifier system. Sephacryl S-200 matrix was slowly inserted into the chromatographic column length of $60 \mathrm{~cm}$ with a $1 \mathrm{~cm}$ diameter. The dialysis processes were applied to the column, and the elution was carried out using $0.1 \mathrm{M}$ phosphate buffer $(\mathrm{pH} \mathrm{7)}$ solution with a flow rate of 0.5 $\mathrm{mL} / \mathrm{min}$. The elution process was observed by the detector at the wavelength of $280 \mathrm{~nm}$ and $254 \mathrm{~nm}$. Every $3 \mathrm{~mL}$ of 
eluent fraction was automatically collected in a tube. The collected fractions were grouped based on the retention time in the column. These fractions were determined their inhibitory activity against $V$. harveyi using the disk diffusion method (Lisboa et al. 2006). The Sephacril S-200 column was also used to determine the molecular weight of the protein fractions by creating a standard curve of the eluents volume versus the log of protein standard molecular weight.

\section{Effect of $\mathrm{pH}$ on the stability of antimicrobial compounds}

The selected fractions from the dialysis were treated with solutions of $\mathrm{pH} 3,5,7,9$, and 11. The acid solution was $1 \mathrm{M} \mathrm{HCl}$, while the alkaline solution was $1 \mathrm{M} \mathrm{NaOH}$. The $\mathrm{pH}$ treatments were conducted at room temperature $\left( \pm 26^{\circ} \mathrm{C}\right)$ for two hours. The inhibitory activity assay was conducted against $V$. harveyi using the disk diffusion method (Joshi et al. 1976).

\section{Effect of temperature on the stability of the antimicrobial compound}

The selected fractions from the dialysis were heated at $50^{\circ} \mathrm{C}$ and $100^{\circ} \mathrm{C}$ for 10 and 20 minutes. The inhibitory activity was conducted against $V$. harveyi using the disk diffusion method (Joshi et al. 1976).

\section{RESULTS AND DISCUSSION}

\section{Inhibitory activity of selected Bacillus sp. isolates}

The inhibitory activity of the selected Bacillus sp. against $V$. harveyi showed that all selected Bacillus sp. could inhibit the growth of $V$. harveyi (Table 1). The inhibitory activity of the three selected Bacillus sp was categorized as high inhibition against $V$. harveyi. The highest inhibition index against $V$. Harvey $i$ was performed by the Bacillus sp Lts40, with an inhibitory index of 7,0.

The mixed culture assay in a liquid media showed that the Bacillus sp. Lts40 isolate could inhibit the growth of $V$. harveyi (Figure 1) in all inoculum ratios. The highest $V$. harveyi population was at the 1:10 ratio. The approximate cell density of Bacillus sp. Lts40 at the 1:10 ratio was 61,5 x $10^{10} \mathrm{CFU} / \mathrm{mL}$. Meanwhile, the cell density of $V$. harveyi was $6,8 \times 10^{10} \mathrm{CFU} / \mathrm{mL}$. Growth inhibitory activity of Bacillus sp Lts40 at inoculum ratio of $1: 1$ against $V$. harveyi was $81.8 \%$. The highest growth inhibition of $V$. harveyi by Bacillus sp Lts40 (88.7\%) was obtained at the inoculum ratio of 1:10.

\section{Optimum production of antimicrobial compounds during the growth of Bacillus Lts 40}

The bacterial growth of Bacillus sp. Lts40 in SWC medium showed that the end of the log phase was achieved at 18 hours of incubation. The inhibitory activity was started at 6 hours up to the end of incubation. However, the highest inhibitory activity was obtained at 72 hours of incubation (Figure 2).

\section{Characteristics of antimicrobial compounds of Bacillus sp. Lts40 isolate}

The results of the protein precipitation using ammonium sulfate $\left(\left(\mathrm{NH}_{4}\right)_{2} \mathrm{SO}_{4}\right)$ showed that both supernatant and precipitated protein showed inhibitory activity against $V$. harveyi (Figure 3 ). The concentrations of protein precipitates were relatively not significantly different in different ammonium sulfate concentrations. However, the highest inhibitory activity of the precipitates in the treatment of $60-70 \%\left(\mathrm{NH}_{4}\right)_{2} \mathrm{SO}_{4}$. However, the highest specific inhibitory activity was obtained from the precipitate resulted from $30-40 \%\left(\mathrm{NH}_{4}\right)_{2} \mathrm{SO}_{4}$ treatment on the precipitates before or after dialysis (Table 2). The dialysis process could increase the specific inhibition activity up to 2.4 times.

Table 1. Inhibitory activity of the three selected Bacillus sp. isolated from shrimp ponds against Vibrio harveyi using a doublelayer method assay (average \pm standard error; $n=3$ ).

\begin{tabular}{lccc}
\hline $\begin{array}{c}\text { Bacillus sp. } \\
\text { isolate }\end{array}$ & $\begin{array}{c}\text { Disk diameter } \\
(\mathbf{m m})\end{array}$ & $\begin{array}{c}\text { Diameter of } \\
\text { inhibition } \\
\text { zone (mm) }\end{array}$ & $\begin{array}{c}\text { Inhibition } \\
\text { index }\end{array}$ \\
\hline Lts40 & $2.5 \pm 0$ & $20.0 \pm 0.6$ & $7.0 \pm 0.2$ \\
Lts36 & $2.5 \pm 0$ & $11.5 \pm 0.3$ & $3.6 \pm 0.1$ \\
Ltw54 & $2.5 \pm 0$ & $13.0 \pm 0.3$ & $4.2 \pm 0.1$ \\
\hline
\end{tabular}

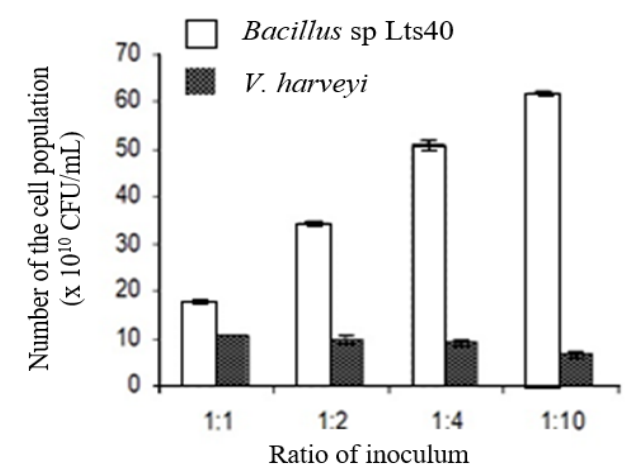

A

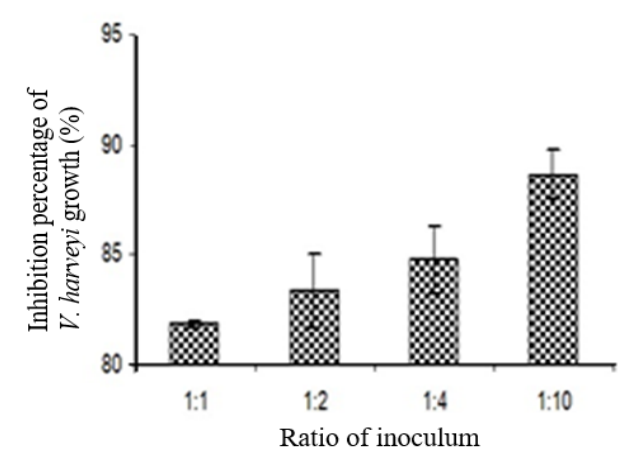

B

Figure 1. Inhibitory activity of Bacillus sp. Lts40 against Vibrio harveyi, (A) Number of cells population of Bacillus sp Lts40 and V. harveyi in the mixed culture with different ratio of inoculum, (B) The percentage of growth inhibition of $V$. harveyi by Bacillus sp Lts40. Bars indicate standard error $(n=3)$. 


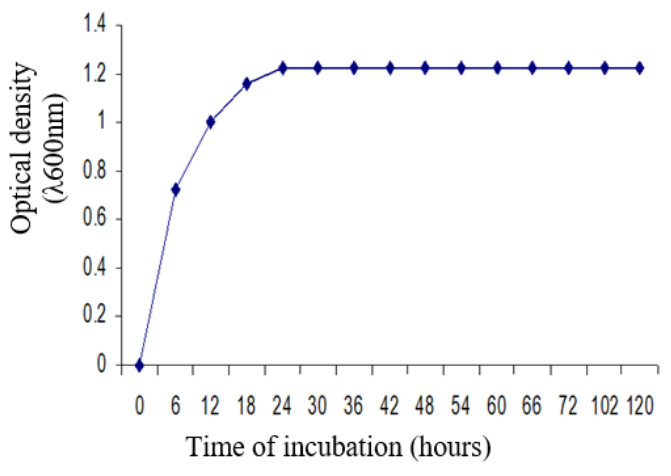

A

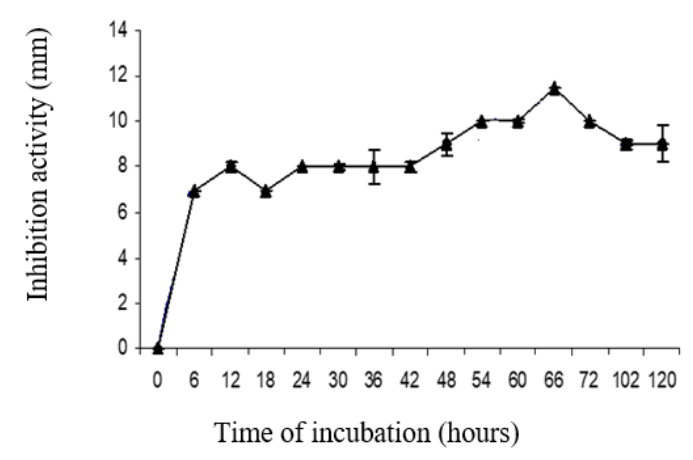

B

Figure 2. The optimum production of antimicrobial compounds during the growth of Bacillus sp. Lts40. (A) the growth curve of Bacillus sp. Lts 40 isolate in seawater complete medium, and (B) Inhibitory activity of supernatant of the culture medium of Bacillus sp Lts40. The inhibitory activity was determined using a disk diffusion method. Bars indicate standard error $(n=3)$.

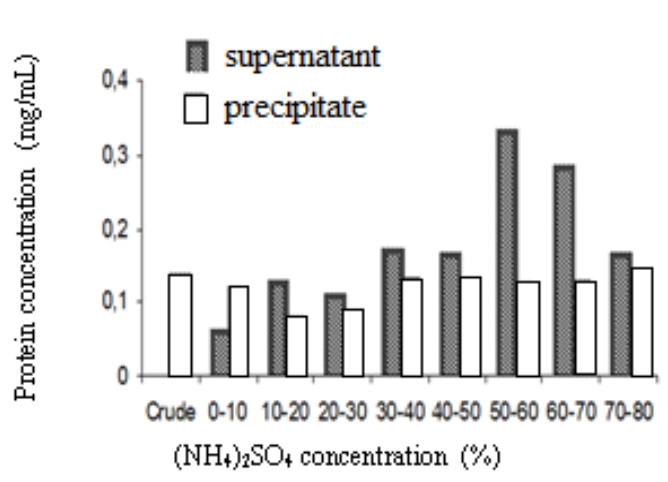

A

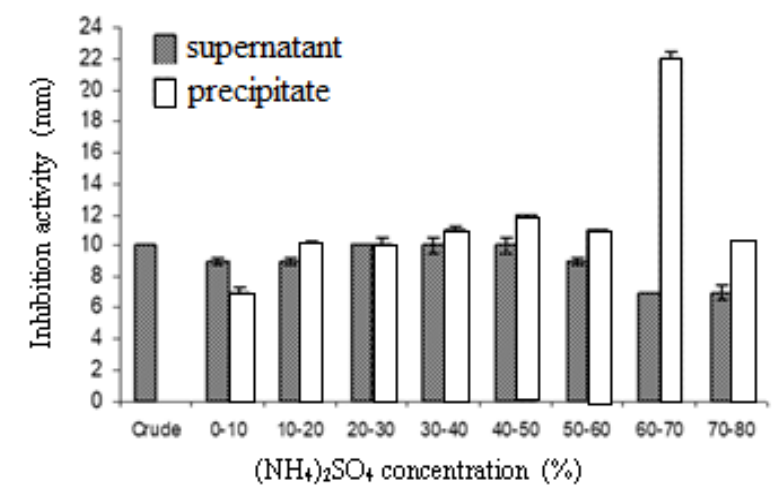

B

Figure 3. Inhibitory activity of antimicrobial compounds of Bacillus sp. Lts40 against Vibrio harveyi after protein precipitation using ammonium sulfate $\left(\left(\mathrm{NH}_{4}\right)_{2} \mathrm{SO}_{4}\right)$. A. Protein concentration in the supernatant and precipitate after precipitation using different concentrations of $\left(\left(\mathrm{NH}_{4}\right)_{2} \mathrm{SO}_{4}\right)$. B. Inhibitory activity of the supernatant and precipitate after precipitation using different concentrations of $\left.\left(\mathrm{NH}_{4}\right)_{2} \mathrm{SO}_{4}\right)$. The inhibitory activity was determined using a disk diffusion method. Bars indicate standard error $(\mathrm{n}=3)$.

Purification of Bacillus sp. Lts40 antimicrobial substance using a Hi Prep 16/60 Sephacryl S-200 highresolution column with a Sweden AKTA purifier system resulted in 15 peak protein fractions (Figure 4). All eluent fractions showed antimicrobial activity against $V$. harveyi. However, the highest antimicrobial activity against $V$. harveyi $(30 \mathrm{~mm})$ was no 21 fraction (Figure 5). Concentration of the protein fraction no 21 was 0.0167 $\mathrm{mg} / \mathrm{mL}$. Based on the standard protein retention time, the molecular weight of this protein fraction is $47.38 \mathrm{kDa}$.

\section{Stability of antimicrobial compounds from Bacillus sp. Lts40 at different $\mathrm{pH}$ and temperature}

The inhibitory activity of antimicrobial compounds from Bacillus sp Lts40 at different $\mathrm{pH}(\mathrm{pH} 3-11)$ remained stable (Figure 6) and not significantly different among $\mathrm{pH}$ treatments. However, the optimum inhibitory activity against $V$. harveyi was obtained at $\mathrm{pH} 5$ with a diameter of inhibition was $22 \mathrm{~mm}$. Furthermore, the stability of inhibitory activity of antimicrobial compounds from Bacillus sp. Lts40 was determined at different temperatures and the length of exposure. The results showed that the antimicrobial compounds remained stable after being heated at $50^{\circ} \mathrm{C}$ and $100^{\circ} \mathrm{C}$ for 10 and 20 minutes (Table 3).

\section{Discussion}

Three selected Bacillus sp. isolates have antimicrobial activity against $V$. harveyi. The Bacillus sp. Lts40 performed the highest inhibitory activity against $V$. harveyi. Bacillus sp. can produce antimicrobial compounds such as bacteriocin and polypeptide antibiotics. Bacillus subtilis can produce an antimicrobial substance such as Cerein (Oscariz and Pisabarro 2000). Factors that can affect the inhibitory activity of antimicrobial compounds are their functional groups, the resistance of the bacterial targets, the concentration of the active substances, and the density of the target bacteria (Rachmaniar 1997). Moreover, other factors influencing antimicrobial activity are 1) type, number, and growth phase of bacteria, 2) concentration of antimicrobial compounds, 3) temperature and length of contact time, and 4) physic-chemical properties of substrates such as $\mathrm{pH}$, water content, and surface tension (Frazier and Wasthoff 1981). 


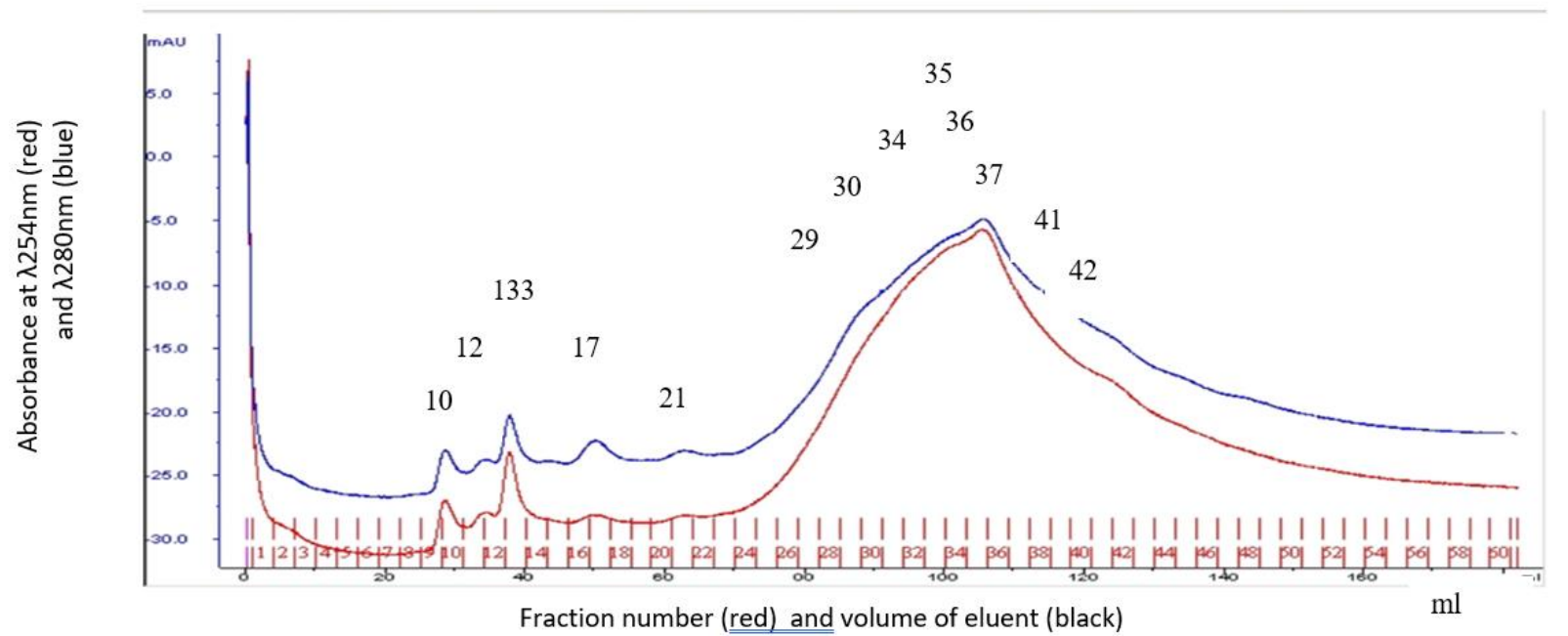

Figure 4. The absorbance of protein fractions from Bacillus sp. Lts 40 at the wavelength of $254 \mathrm{~nm}$ (red) and $280 \mathrm{~nm}$ (blue). The number in the graph were the number of fractions that analyzed for antibacterial activity. The number in the graph were the number of fractions that were analyzed for antibacterial activity against Vibrio harveyi. The purification was conducted using a Hi Prep 16/60 Sephacryl S200 High Resolution, with a Sweden AKTA purifier system.

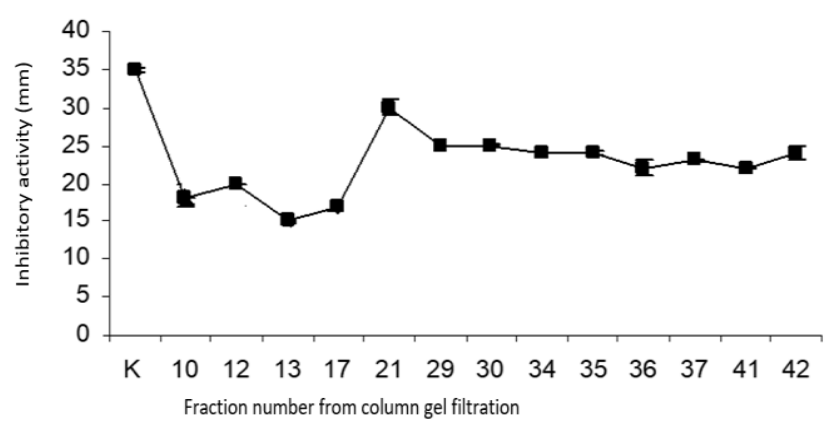

Figure 5. The inhibitory activity of the 15 selected fractions from Bacillus sp. Lts40 against $V$. harveyi. The purification was conducted using a Hi Prep 16/60 Sephacryl S-200 high resolution, with a Sweden AKTA purifier system. The inhibitory activity was determined using a disk diffusion method. Bars indicate standard error $(n=3)$ and $K$ is control of supernatant.

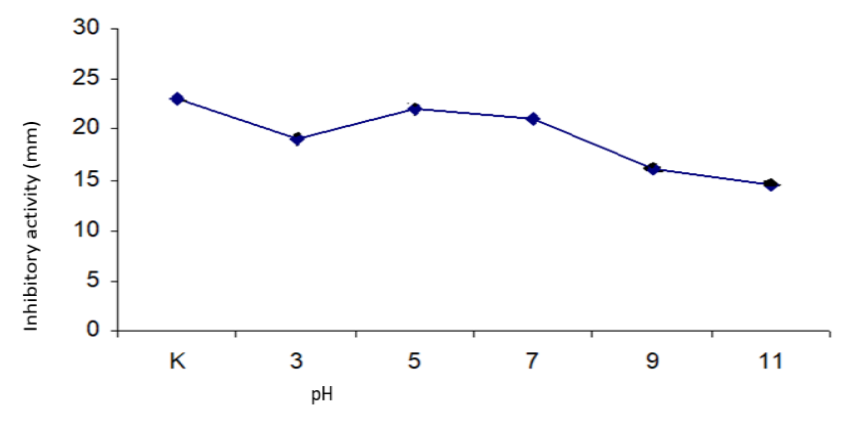

Figure 6. Inhibitory activity of the antimicrobial compounds from Bacillus sp. Lts40 at the $\mathrm{pH}$ range of 3-11 for two hours at room temperature $\left( \pm 26^{\circ} \mathrm{C}\right)$. The inhibitory activity was determined using a disk diffusion method. $\mathrm{K}$ indicates control of supernatant.

Table 2. Antimicrobial activity of protein precipitates from culture media of Bacillus sp Lts40 from the best ammonium sulfate precipitation before and after purification using membrane dialysis (average \pm standard error; $n=3$ ).

\begin{tabular}{ccccccccc}
\hline \multirow{2}{*}{$\begin{array}{c}\text { Concentration of } \\
\text { ammonium } \\
\text { sulfate }(\%)\end{array}$} & $\begin{array}{c}\text { Protein } \\
\text { concentration } \\
(\mathbf{m g} / \mathbf{m L})\end{array}$ & $\begin{array}{c}\text { Antimicrobial } \\
\text { activity }(\mathbf{m m})\end{array}$ & $\begin{array}{c}\text { Specific activity } \\
(\mathbf{m m} / \mathbf{m g} / \mathbf{m L})\end{array}$ & & $\begin{array}{c}\text { Protein } \\
\text { concentration } \\
(\mathbf{m g} / \mathbf{m L})\end{array}$ & $\begin{array}{c}\text { Antimicrobial } \\
\text { activity }(\mathbf{m m})\end{array}$ & $\begin{array}{c}\text { Specific activity } \\
(\mathbf{m m} / \mathbf{m g} / \mathbf{m L})\end{array}$ \\
\hline $30-40$ & $0.0192 \pm 0.0005$ & $19 \pm 1.5$ & $989.58 \pm 59.21$ & & $0.0077 \pm 0.0006$ & & $18 \pm 1.2$ & $2,337.66 \pm 347.72$ \\
$60-70$ & $0.1653 \pm 0.0043$ & $35 \pm 2.5$ & $211.74 \pm 10.00$ & & $0.1104 \pm 0.0075$ & $30 \pm 1.7$ & $271.74 \pm 27.85$ \\
\hline
\end{tabular}

Table 3. Inhibitory activity of antimicrobial compounds from Bacillus sp. Lts40 after temperature treatments (average \pm standard error; $\mathrm{n}=3$ )

\begin{tabular}{ccccc}
\hline $\begin{array}{c}\text { Temperature } \\
\text { treatments }\left({ }^{\circ} \mathbf{C}\right)\end{array}$ & $\begin{array}{c}\text { Length of temperature } \\
\text { treatments (minutes) }\end{array}$ & Disk diameter (mm) & Inhibition zone (mm) & Inhibition index \\
\hline 50 & 10 & $2.5 \pm 0.0$ & $20 \pm 1.0$ & $8.0 \pm 0.4$ \\
& 20 & $2.5 \pm 0.0$ & $19 \pm 1.0$ & $7.6 \pm 0.4$ \\
100 & 10 & $2.5 \pm 0.0$ & $16 \pm 0.6$ & $6.4 \pm 0.2$ \\
& 20 & $2.5 \pm 0.0$ & $15 \pm 1.0$ & $6.0 \pm 0.4$ \\
\hline
\end{tabular}


Bacillus sp. Lts40 isolate produced extracellular antimicrobial compounds produced during bacterial growth, either in the log phase or stationary phase, and the optimum production was in 72 hours of incubation. Therefore, its culture supernatant showed inhibitory activity against $V$. harveyi. Antimicrobial compounds produced by Bacillus sp. Lts 40 isolate is a protein. And the protein is produced during bacterial growth. So, this indicates that the antimicrobial compound of Bacillus sp. Lts40 isolate is a bacteriocin. Bacteriocins are proteins or peptides generally produced at the exponential growth phase and synthesized in the ribosome (Ray and Daeschel 1981). The inhibitory activity seemed to decrease after 72 hours of incubation, it may be indicating the reduction of digestive enzymes, reabsorption of antimicrobe (Dajani and Wannamaker 1969), or releasing proteases from cell autolysis that degrade the antimicrobial compounds (Jo et al. 1996).

Precipitation of antimicrobial compounds indicated that the treatment of $60-70 \%$ ammonium sulfate was the best concentration in precipitating antimicrobial compounds from Bacillus sp. Lts40. However, precipitation of antimicrobial compounds using 30-40\% ammonium sulfate resulted in the best specific antimicrobial activity. Dialysis processes that wash out ammonium sulfate affected the inhibitory activity of antimicrobial compounds. Therefore, dialysis processes could increase the specific inhibitory activity of the antimicrobial compounds up to 2.4 times.

The highest antimicrobial activity of purified antimicrobial substance of Bacillus sp. Lts40 is a protein that has molecular weight of $47.38 \mathrm{kDa}$. This result supports the indication that the antimicrobial substance of Bacillus sp. Lts40 is a bacteriocin. Bacteriocins are proteinaceous antimicrobial agents that are classified into three classes. Class I bacteriocins are known as antibiotics which have a molecular weight of less than five kDa. Class II bacteriocins have a molecular weight of less than ten $\mathrm{kDa}$, and Class III bacteriocins consist of proteins with a molecular weight of more than $30 \mathrm{kDa}$ (Parada et al. 2007; Mokoena 2017). Based on its molecular weight, the antimicrobial compound from Bacillus sp. Lts40 is presumably a class III bacteriocin. Several Bacillus spp produce bacteriocins with different ranges of molecular weight. Molecular weight of bacteriocins produced by Bacillus coagulans is 3-4 $\mathrm{kDa}$ (Marrec 1998), and bacteriocins from Bacillus polyfermenticus is $14.3 \mathrm{kDa}$ (Lee et al. 2001). Other characteristics of bacteriocins produced by other bacteria are presented in Table 4 .

The antimicrobial substance from Bacillus sp. Lts40 was stable in a pH range of 3-11. Inhibitory activity of Bacillus sp. Lts40 against $V$. harveyi was stable in acidic and alkaline conditions. The stability of antimicrobial compounds in a wide $\mathrm{pH}$ range due to their amino acid compositions contains cysteine. It will form disulfide bonds and have more than one active site. If there is a change in $\mathrm{pH}$, it will change the degree of ionization of the ionic clusters of amino acids of the proteins. Increasing the inhibitory activity due to the ionization of the ionic group on the active site leads to a more stable conformation (Denniston et al. 2001).

Table 4. The characteristics of bacteriocin from several bacteria

\begin{tabular}{|c|c|c|c|c|}
\hline Bacterial isolates & $\begin{array}{c}\text { Molecular } \\
\text { weight }(k D a)\end{array}$ & Stability & Purification method & References \\
\hline Brevibacterium linens & 95 & $\begin{array}{l}\text { Stable at } 45^{\circ} \mathrm{C} 60 \mathrm{~min} \text {, no activity } \\
\text { at } 60^{\circ} \mathrm{C}\end{array}$ & Gel filtration, SDS-PAGE & Kato et al. (1991) \\
\hline Lactobacillus brevis & $10-30$ & $\begin{array}{l}\text { Stable at a broad range of } \\
\text { temperatures and } \mathrm{pH}\end{array}$ & Ion exchange & Benoit et al. (1991) \\
\hline Pediococcus acidilactici & 3,6 & $\begin{array}{l}\text { Stable at } 100^{\circ} \mathrm{C} 40 \mathrm{~min} \text {, Stable at } \\
\text { pH } 2-11\end{array}$ & $\begin{array}{l}\text { Ion exchange, hydrophobic } \\
\text { chromatography, HPLC, SDS- } \\
\text { PAGE }\end{array}$ & Cintas et al. (1995) \\
\hline Bacillus coagulans $\mathrm{I}_{4}$ & $3-4$ & Stable at $60^{\circ} \mathrm{C} 90 \mathrm{~min}, \mathrm{pH} 4-8$ & SDS-PAGE & Marrec (1998) \\
\hline $\begin{array}{l}\text { Lactobacillus acidophilus } \\
\text { 30SC }\end{array}$ & 3,5 & $\begin{array}{l}\text { Stable at } 121^{\circ} \mathrm{C} 20 \mathrm{~min}, \text { stable at } \\
\text { pH 3-10 }\end{array}$ & $\begin{array}{l}\text { hydrophobic chromatography, } \\
\text { SDS-PAGE }\end{array}$ & Oh et al. (2000) \\
\hline Bacillus polyfermenticus & 14,3 & $\begin{array}{l}\text { No activity at }>70^{\circ} \mathrm{C} \\
\text { stable at pH } 2-9\end{array}$ & SDS-PAGE & Lee et al. (2001) \\
\hline Bacillus licheniformis & 2 & $\begin{array}{l}\text { Stable at } 100^{\circ} \mathrm{C} \\
\text { Stable at broad range of } \mathrm{pH}\end{array}$ & Gel filtration, SDS-PAGE & Martirani et al. (2001) \\
\hline Bacillus cereus & $1-8$ & $\begin{array}{l}\text { Stable at } 75^{\circ} \mathrm{C} 15^{\prime} \text {, stable at } \mathrm{pH} 3- \\
10\end{array}$ & SDS-PAGE & $\begin{array}{l}\text { Torkar and Matijasic } \\
(2003)\end{array}$ \\
\hline $\begin{array}{l}\text { Lactobacillus palntarum } \\
\text { F1 \& Lactobacillus brevis } \\
\text { OG1 }\end{array}$ & $1-10$ & $\begin{array}{l}\text { Stable at } 121^{\circ} \mathrm{C} 10 \mathrm{~min} \text {, stable at } \\
\text { pH 2-6 }\end{array}$ & Ultrafiltration & Chythanya et al. (2002) \\
\hline $\begin{array}{l}\text { Streptococcus } \\
\text { thermophilus ACA-DC } \\
0001\end{array}$ & 30 & $\begin{array}{l}\text { Stable } 50^{\circ} \mathrm{C} 10 \mathrm{~min} \\
\text { Stable at } \mathrm{pH} 2-10\end{array}$ & $\begin{array}{l}\text { Gel filtration, ion exchange, } \\
\text { and SDS-PAGE }\end{array}$ & $\begin{array}{l}\text { Anastasios and George } \\
(2003)\end{array}$ \\
\hline Bacillus amyloliquefaciens & 5 & $\begin{array}{l}\text { Stable at } 100^{\circ} \mathrm{C} 60 \mathrm{~min} \text {, stable at } \\
\text { pH 2-8 }\end{array}$ & SDS-PAGE & Denniston et al. (2001) \\
\hline Bacillus sp., Lts40 & 47.38 & $\begin{array}{l}\text { Stable at } 50-100^{\circ} \mathrm{C} 20 \mathrm{~min} \text {, stable } \\
\text { at } \mathrm{pH} 3-11\end{array}$ & Gel filtration & This study \\
\hline
\end{tabular}


The antimicrobial compound of Bacillus sp. Lts40 is resistant to heat treatment up to a temperature of $100^{\circ} \mathrm{C}$ for 20 minutes. This stability is possibly due to the amino acid composition of antimicrobial compounds from Bacillus sp. Lts40 naturally supports stability in complex circumstances. The disulfide bonds probably make this antimicrobial substance more heat stable. In general, some bacteriocins are resistant to heat and acidic conditions (Bhunia et al. 1988; Ahn and Stiles 1990; Kone and Fung 1992).

This study clearly shows that the Bacillus sp. Lts40 isolate has potential application as a probiotic agent in shrimp ponds to control the growth of $V$. harveyi that causes luminous vibriosis diseases. This bacterial isolate can inhibit the growth of $V$. harveyi up to $88.7 \%$. Moreover, the antimicrobial substance produced by the isolate is a protein that is stable after heat shock treatments up to $100^{\circ} \mathrm{C}$. So, this substance is potentially to be developed and produced as an anti- $V$. harveyi product that can be applied in a shrimp hatchery.

In conclusion, inhibitory activity of three selected Bacillus sp. against $V$. harveyi was categorized as high. The highest inhibition index was performed by Bacillus sp Lts40 isolate. The highest growth inhibition of $V$. harveyi (88.7\%) was performed by Bacillus sp. Lts40. The optimum production of antimicrobial compounds was obtained at 72 hours of incubation. Antimicrobial precipitation by $30-40 \% \quad\left(\mathrm{NH}_{4}\right)_{2} \mathrm{SO}_{4}$ had the highest specific inhibition activity, and dialysis processes could increase its specific inhibition activity up to 2.4 times. A gel filtration chromatography resulted in 15 peaks of protein fractions that have antimicrobial activity against $V$. harveyi. The highest inhibitory activity was protein fraction no 21 with a molecular weight of $47.38 \mathrm{kDa}$. The antimicrobial compound from Bacillus sp Lts40 remains stable at a pH range of $3-11$ and a temperature of $100^{\circ} \mathrm{C}$ for 20 minutes.

\section{ACKNOWLEDGEMENTS}

This study was supported by the Basic Research Grant of the Directorate of Higher Education, Ministry of Education, Culture, Research and Technology, Indonesia.

\section{REFERENCES}

Ahn C, Stiles ME. 1990. Plasmid associated bacteriocin production by a strain Carnobacterium piscicola from meat. Appl Environ Microbiol 56 (8): 2503-2510. DOI: 10.1128/aem.56.8.2503-2510.1990.

Anastasios A, George K. 2003. Purification and characterization of thermophilic ST-1, a novel bacteriocin produced by Streptococcus thermophilus ACA-DC 0001. J Food Sci Technol 83 (5): 365-378. DOI: 10.1051/lait:2003024.

Benoit V, Mathis R, Lefebure G. 1994. Characterization of Breviscin 27, a bacteriocin synthesized by Lactobacillus brevis SB27. Curr Microbiol 34 (3): 173-179. DOI: 10.1007/BF01575986.

Bhunia AK, MC Johnson, Ray B 1988. Purification, characterization, and antimicrobial spectrum of a bacteriocin produced by Pediococcus acidilactici. J Appl Bacteriol 65 (4): 261-268. DOI: 10.1111/j.13652672.1988.tb01893.x.
Bradford MM. 1976. A rapid and sensitive method for quantitating microgram quantities of protein utilizing principles of protein-dye binding. Anal Biochem 7 (72): 248-254. DOI:10.1016/00032697(76)90527-3.

Chythanya R, Indrani K, Iddya K. 2002. Inhibition of shrimp pathogenic vibrios by a marine Pseudomonas 1-2 strain. Aquaculture 208 (1-2): 1-10. DOI: 10.1016/S0044-8486(01)00714-1.

Cintas LM, Rodriguez JM, Fernandez MF, Sletten K, Nes IF, Hernandez PE, Holo H. 1995 Isolation and characterization of Pediocin L50 a new bacteriocin from Pediococcus acidilactici with a broad inhibitory spectrum. Appl Environ Microbiol 61 (7): 2643-2648. DOI: 10.1128/aem.61.7.2643-2648.1995.

Dajani AS, Wannamaker LW. 1969. Demonstrated a bactericidal substance against beta-hemolytic streptococci in supernatant fluid of

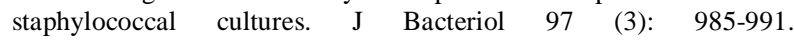
DOI:10.1128/jb.97.3.985-991.1969.

De Souza Valente C, Wa AHL. 2021. Vibrio and major commercially important vibriosis diseases in decapod crustaceans. J Invertebr Pathol 181: 107527. DOI: 10.1016/j.jip.2020.107527

Denniston. 2001. General, Organic and Chemistry Eds-3. New York: Mc Graw Hill.

Frazier WC, Westhoff DC. 1981. Food Microbiology. Tata Mc Graw-Hill, New Delhi.

Harpeni E, Santoso L, Supono S, Wardiyanto W, Widodo A, Yolanda L. 2018. Effects of dietary probiotic Bacillus sp. D2. 2 and prebiotic sweet potato extract on growth performance and resistance to Vibrio harveyi in Pacific white shrimp, Litopenaeus vannamei. Aquac Indonesiana 18 (2): 55-61. DOI: 10.21534/ai.v18i2.107.

Irina VP, Philippe B, Bernard V, Bernard F. 2001. In vitro antiHelicobacter pylori activity of the probiotic strain B. subtilis 3 is due to secretion of antibiotic. J Antimicrob Agent Chemother 45 (11): 3156-3161. DOI: 10.1128/AAC.45.11.3156-3161.2001.

Jo YB, Kyung MB, Song-Koo K, Hong-ki J. 1996. Evaluation at optimum conditions for bacteriocin production from Lactobacillus sp. JB-42 isolated from kimchi. J Microbiol Biotechnol 6 (1): 63-67.

Joshi VK, Sharma S, Rana NS. 2006. Production, purification, stability and efficacy of bacteriocin from isolates of natural lactic acid fermentation of vegetables. J Food Technol Biotechnol 44 (3): 435. https://hrcak.srce.hr/109971 [10-092021].

Kato F, Eguchi Y, Nakano M, Oshima T, Murata A. 1991 Purification and characterization of Linecin A, a bacteriocin of Brevibacterium linens. J Agric Biol Chem 55: (1): 161-166. DOI: 10.1271/bbb1961.55.161.

Kone K, Fung YC. 1992. Understanding bacteriocins and their uses in foods. Dairy, food and environmental sanitation.

Kumar TS, Vidya R, Kumar S, Alavandi SV, Vijayan KK. 2017. Zoea-2 syndrome of Penaeus vannamei in shrimp hatcheries. Aquaculture 497 (2017): 759-767. DOI: 10.1016/j.aquaculture.2017.07.022.

Lee KH, Jun KD, Kim WS, Paik HO. 2001. Partial characterization of polyfermenticin SCD, a newly identified bacteriocin of Bacillus polyfermenticus. Appl Microbiol 32 (3): 146-151. DOI: 10.1046/j.1472-765x.2001.00876.x.

Lisboa MP, Bonatto D, Bizani D, Henriques JAP, Brandelli A. 2006 Characterization of a bacteriocin-like substance produced by Bacillus amyloliquefaciens isolated from the Brazilian Atlantic Forest. Intl Microbiol 9 (2): 111-118.

Marrec L. 1998. Coagulin, a bacteriocin-like inhibitory substance produced by Bacillus coagulans I4. J Appl Microbiol 85 (1): 42-50. DOI: 10.1046/j.1365-2672.1998.00466.x.

Martirani LM, Varcamonti, Naclerio G, Felice MD. 2002. Purification and partial characterization of bacillon 490 a novel bacteriocin produced by a thermophilic strain of Bacillus licheniformis. J Microbiol Cell Factor 1 (1): 1. DOI:10.1186/1475-2859-1-1.

Mokoena MP. 2017. Lactic acid bacteria and their bacteriocins: classification, biosynthesis, and applications against uropathogens: a mini-review. Molecules 22 (8): $1255 . \quad$ DOI: 10.3390/molecules22081255.

Oh S, Kim SH, Worobo RW. 2000. Characterization and purification of a bacteriocin produced by a potential probiotic culture Lactobacillus acidophilus 30SC. J Sci Technol 83 (12): 2747-2752. DOI: 10.3168/jds.S0022-0302(00)75169-1.

Oscariz JC, Pisabarro AG. 2000. Characterization and mechanism of action of cerein 7, a bacteriocin produced by Bacillus cereus $\mathrm{Bc} 7$. J $\begin{array}{llll}\text { Appl Microbiol } 89 & \text { (2): } 361-369 . & \text { DOI:10.1046/j.1365- }\end{array}$ 2672.2000.01123.x. 
Parada JL, Caron CR, Medeiros ABP, Soccol CR. 2007. Bacteriocins from lactic acid bacteria: purification, properties and use as preservatives. Braz Arch Biol Technol 50 (3): 521-542. DOI: 10.1590/S1516-89132007000300018

Rachmaniar R. 1997. Potensi spon asal kepulauan spermonde sebagai antimikroba. Seminar Perikanan Indonesia II. Ujung Pandang 2-3 Desember 1997. [Indonesian]

Ray B, Daeschel M. 1992. Food Biopreservative of Microbiology Origin. CRC Press, London.
Roza DZ. 1993. Teknik penanggulangan penyakit udang menyala di hatchery melalui pengendalian populasi bakteri. Jurnal Penelitian Budidaya Pantai 9: 127

Torkar KG, Matijasic BB. 2003. Partial characterization of bacteriocins produced by Bacillus cereus isolates from milk and milk products. Food Technol Biotechnol 41 (2): 121-129. https://hrcak.srce.hr/file/163966 [12-092021].

Verschuere L, Rombaut G, Sorgeloos P, Verstraete W. 2000. Probiotic bacteria as control agent in aquaculture. J Mol Biol Biotechnol 64 (4): 655-671. DOI: 10.1128/MMBR.64.4.655-671.2000. 